OLIVEIRA, F.R., MACHADO, F.M.E. e COELHO, H.E. Estudo anatomopatológico de fígados que levam a condenação total de carcaça, na linha de inspeção, durante o abate de frangos de corte (Gallus gallus domesticus) na região do Triângulo Mineiro. PUBVET, Londrina, V. 8, N. 2, Ed. 251, Art. 1662, Janeiro, 2014.

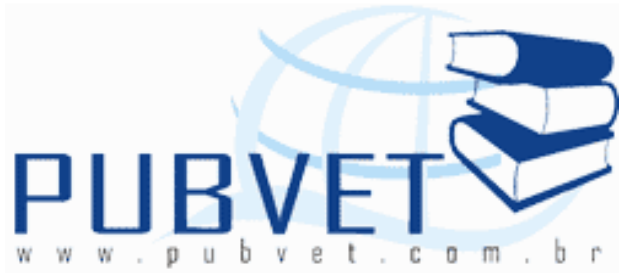

PUBVET, Publicações em Medicina Veterinária e Zootecnia.

\title{
Estudo anatomopatológico de fígados que levam a condenação total de carcaça, na linha de inspeção, durante o abate de frangos de corte (Gallus gallus domesticus) na região do Triângulo Mineiro
}

Francislaine Rosa Oliveira1, Flavia Maria Esteves Machado², Humberto Eustáquio Coelho ${ }^{3}$

${ }^{1}$ Aluna do curso de Mestrado em Sanidade e Produção Animal dos Trópicos do Curso de Medicina Veterinária da Universidade de Uberaba;

${ }^{2}$ Professora do curso de Medicina Veterinária da Universidade de Uberaba;

${ }^{3}$ Orientador e Professor do curso de Medicina Veterinária e da Pós Graduação da Universidade de Uberaba.

\section{Resumo}

O fígado é a maior glândula do corpo, possuindo maior diversidade de funções. É parenquimatoso e glandular. Fígado de frango pode ser acometido por inúmeras alterações, incluindo as bacterianas, parasitárias, neoplásicas, dentre outras. A condenação de carnes e vísceras impróprias para o consumo visa zelar pela saúde pública, uma vez que a carne de frango e seus subprodutos são fontes de enfermidades transmitidas ao homem. Foram examinados no presente trabalho, macro e microscopicamente, 100 fígados de frangos de corte, com idade de 33 dias e peso de 1,3 a 1,6 kg, que levaram a condenação de toda a carcaça, na linha B de inspeção em um abatedouro localizado na região do Triângulo Mineiro. Macroscopicamente, observou-se uma coerência entre os achados descritos na literatura consultada, tais como: fígados 
OLIVEIRA, F.R., MACHADO, F.M.E. e COELHO, H.E. Estudo anatomopatológico de fígados que levam a condenação total de carcaça, na linha de inspeção, durante o abate de frangos de corte (Gallus gallus domesticus) na região do Triângulo Mineiro. PUBVET, Londrina, V. 8, N. 2, Ed. 251, Art. 1662, Janeiro, 2014.

aumentados de volume, com manchas avermelhadas, esverdeadas, amareladas, com áreas esbranquiçadas e friáveis. Microscopicamente, as lesões encontradas na maioria dos fígados foram de infiltrados de heterófilos, seguidas de aglomerados de células neoplásicas, o que permitiu concluir que o diagnóstico etiológico baseado nas alterações macro e microscópicas é compatível com colibacilose ( $80 \%)$ e leucose mielóide (20\%), respectivamente.

Palavras-chave: Abate de frangos; exame anatomopatológico de fígado; inspeção de fígados; colibacilose aviária.

\section{Abstract}

Liver is the largest gland in the body, which has a great diversity of functions. It is parenchymal and glandular. Chicken livers may undergo several alterations, including bacterial, parasitic, neoplastic, among other. Chicken meat and its byproducts are sources of diseases transmitted to humans. That is why in order to ensure the public health, meat and viscera are considered unfit for consumption. In this research were examined, macroscopically and microscopically, 100 chicken livers, with an average age of 33 days, weight 1,3 to $1,6 \mathrm{~kg}$, that led the loss of the entire carcass, in line B of a slaughterhouse inspection, located in the region of the Triângulo Mineiro. Macroscopically, it was possible to observe a coherence with the data describe by the literature such as liver with increased volume, reddish, greenish, yellowish, whitish spots and friable. Microscopically, the lesions found in most livers were infiltrated with heterophile, followed by neoplastic cells clustered. Thus it was possible to conclude that the etiologic diagnosis in macro and microscopically alterations is compatible with colibacillosis (80\%) and leucosis myeloid (20\%) respectively.

Keywords: Slaughter of chickens; Anatomopathological examination of liver; Inspection of livers; Avian colibacillosis. 
OLIVEIRA, F.R., MACHADO, F.M.E. e COELHO, H.E. Estudo anatomopatológico de fígados que levam a condenação total de carcaça, na linha de inspeção, durante o abate de frangos de corte (Gallus gallus domesticus) na região do Triângulo Mineiro. PUBVET, Londrina, V. 8, N. 2, Ed. 251, Art. 1662, Janeiro, 2014.

\section{INTRODUÇÃO}

Segundo dados da ABEF (Associação Brasileira dos Exportadores de Frangos) de 2006, o Brasil exportou nos últimos três anos o equivalente a seis milhões de toneladas de carne de frango, adquirindo em 2004 o título de primeiro lugar absoluto nas exportações do produto, tanto em receita cambial quanto em volume exportado. A receita referente às exportações do produto chegou, em 2008, a US\$ 6,9 bilhões, o que representa um aumento de $40 \%$ se comparado a mesma época do ano de 2007, demonstrando a grande importância do setor. Além de representar um novo recorde histórico, o desempenho em 2008 consolidou a posição do Brasil - obtida pela primeira vez em 2004 - de maior exportador mundial.

Dados de 2012 mostram que a produção de carne de frango, principal produto avícola, foi de 12,645 milhões de toneladas, o que representa uma queda de 3,17\% em relação a 2011. O Brasil manteve a posição de maior exportador mundial e de terceiro maior produtor de carne de frango, atrás dos Estados Unidos e da China. A avicultura brasileira enfrentou em 2012 a maior crise de sua história e as consequências só não foram mais acentuadas por tratar-se de um setor muito sólido, mantendo seus atributos de qualidade, sanidade e sustentabilidade (ABEF, 2013). As estimativas para 2013 são de um crescimento de até $3 \%$ tanto na produção quanto nas exportações de carne de frango (ABEF, 2013).

O serviço oficial de inspeção sanitária dos abatedouros avícolas, representado pelo SIF (serviço de inspeção Federal) do MAPA (Ministério da Agricultura Pecuária e Abastecimento) e suas representações estaduais e municipais, são os órgãos responsáveis pela garantia de qualidade da carne e vísceras para o consumo (PONTES, 2004).

Os critérios de condenação de fígados de frangos (Gallus gallus domesticus), consideram o aspecto visual (cor, forma e tamanho), consistência e odor do órgão, de acordo com o que preconiza a Lei no 1283 de 18 de 
OLIVEIRA, F.R., MACHADO, F.M.E. e COELHO, H.E. Estudo anatomopatológico de fígados que levam a condenação total de carcaça, na linha de inspeção, durante o abate de frangos de corte (Gallus gallus domesticus) na região do Triângulo Mineiro. PUBVET, Londrina, V. 8, N. 2, Ed. 251, Art. 1662, Janeiro, 2014.

dezembro de 1950 (Regulamento de Inspeção Industrial e Sanitária de Produtos de Origem Animal - RISPOA), atualizada pela Portaria no 210 de 10 de novembro de 1998 do MAPA (BARCELOS et al., 2006).

A condenação de carnes e vísceras impróprias para o consumo visa zelar pela saúde pública, uma vez que a carne de frango e seus subprodutos, assim como todos os produtos de origem animal, são uma das mais importantes fontes de enfermidades transmitidas ao homem por alimentos. $O$ fígado de frango "in natura" ou processado é passível de sofrer contaminação bacteriana devido à sua constituição orgânica, condições de obtenção e manipulação (JAY, 1994).

Portanto, o fígado de frango pode apresentar inúmeras alterações que incluem distúrbios circulatórios, degenerativos, inflamatórios e neoplásicos. Muitas lesões hepáticas não são específicas quanto à etiologia, mas fornecem informações importantes sobre a ocorrência de doenças sistêmicas (HOERR, 1996).

Segundo dados de Silva et al. (2012), em um estudo realizado em dois abatedouros avícolas localizados no Estado da Bahia, de 100 fígados examinados, 45,5\% foram positvos para colibacilose; Barcelos et al. (2006) no Estado do Rio Grande do Sul, em dois abatedouros avícolas, observaram 21\% de fígados positivos para Colibacilose em 100 fígados coletados, indicando como causas mais comuns de condenação de carcaças por meio da análise do fígado, a colibacilose.

As alterações hepáticas causadas pela colibacilose apresentam-se de forma difusa no órgão e afetam as membranas internas da cavidade celômica, tais como os sacos aéreos, gerando a condenação de toda a carcaça, o que acarreta grandes perdas econômicas.

Justifica-se com este trabalho, o fato de haver grande percentual de condenações de fígados na linha B de fiscalização, havendo necessidade de exames complementares que identifique cada fígado condenado. 
OLIVEIRA, F.R., MACHADO, F.M.E. e COELHO, H.E. Estudo anatomopatológico de fígados que levam a condenação total de carcaça, na linha de inspeção, durante o abate de frangos de corte (Gallus gallus domesticus) na região do Triângulo Mineiro. PUBVET, Londrina, V. 8, N. 2, Ed. 251, Art. 1662, Janeiro, 2014.

\section{REVISÃO DE LITERATURA}

\subsection{MORFOFISIOLOGIA HEPÁTICA}

O fígado é a maior glândula do corpo. Trata-se de um órgão parenquimatoso, glandular, lobado, de coloração vermelho marmóreo, de consistência frágil e recoberto por uma cápsula de tecido conjuntivo (cápsula de Glisson), que emite ramificações para o interior do órgão, formando uma árvore de tecido conjuntivo, o qual dá sustentação interna para toda a glândula, proporcionando meios para que os ramos da veia porta, da artéria hepática e os canais biliares, assim como os vasos linfáticos, possam alcançar todas as partes do fígado. Nos pintos e em outras aves jovens, o fígado apresenta coloração amarelada, devido aos pigmentos da gema, que continuam sendo absorvidos, antes que o saco vitelínico finalmente seja regredido (BENEZ, 2004; COELHO, 2006).

Segundo Coelho (2006), cada lobo hepático é formado por lóbulos: um agrupamento de células denominadas hepatócitos, que se dispõem em placas orientadas radialmente, formando o que se chama de cordões hepáticos, envolvendo os capilares sinusóides revestidos por uma única camada de células, onde encontramos os macrófagos hepáticos (células de Kupffer).

O fígado das aves possui os cordões hepáticos duplos; os hepatócitos apresentam forma poligonal com seis faces e medem de 20 a 30 micrômetros de diâmetro. O hepatócito apresenta um ou dois núcleos, centrais e arredondados, com um ou mais nucléolos bem evidentes. O hepatócito é a célula de maior versatilidade do organismo. É um tipo celular com funções glandulares endócrinas e exócrinas simultâneas. Além de sintetizar e acumular vários compostos, ainda neutraliza outros e transporta corantes como as porfirinas e bilirrubinas que são eliminadas nas fezes corando as mesmas (BACHA; BACHA, 2003; COELHO, 2006).

O lobo direito é maior, apresentando a vesícula biliar em sua superfície visceral, sendo atravessada pela veia cava caudal. O lobo esquerdo é 
OLIVEIRA, F.R., MACHADO, F.M.E. e COELHO, H.E. Estudo anatomopatológico de fígados que levam a condenação total de carcaça, na linha de inspeção, durante o abate de frangos de corte (Gallus gallus domesticus) na região do Triângulo Mineiro. PUBVET, Londrina, V. 8, N. 2, Ed. 251, Art. 1662, Janeiro, 2014.

subdividido em parte lateral e medial através de uma profunda incisão, conhecida como uma incisura lobaris. A superfície parietal é convexa e fica contra as costelas esternais e o esterno; a superfície visceral é côncava e fica em contato com o baço, o proventrículo, a moela, o duodeno, o jejuno, e o ovário, ou testículo direito. Dois ductos biliares, um de cada lobo, penetram na extremidade distal do duodeno, perto dos ductos pancreáticos; somente o ducto oriundo do lobo direito, é ligado á vesícula biliar. Exceto próximo ao hilo, lóbulos hepáticos são indistintos, devido á ausência de tecido conjuntivo perilobular (DICE; SACK; WENSING, 2004; BELS, 2006).

A árvore de tecido conjuntivo fornece sustentação interna ao fígado. Ao nível da porta, a veia porta e a artéria hepática penetram no tronco da árvore de tecido conjuntivo, e, daí para diante, cada um desses vasos se ramifica, acompanhando a ramificação da árvore. Da mesma forma, os vasos linfáticos e os canais biliares também possuem ramos que correspondem a cada ramo da árvore conjuntiva. Os vasos linfáticos principais e os dois canais biliares principais, um do lobo direito e outro do esquerdo, deixam o fígado pela porta. Os dois canais biliares principais logo se unem para formar um conduto único. A ele se une o canal cístico da vesícula biliar e o canal biliar comum que leva a bile para o duodeno. Por fim, o sangue abandona o fígado pelas veias hepáticas. Essas não caminham pelos ramos da árvore de tecido conjuntivo; suas tributárias (denominadas veia central e veias sublobulares) e elas mesmas, seguem cursos próprios através da substância hepática (onde se associam apenas com um pouco de tecido conjuntivo) e deságuam na veia cava, quando essa entra em contato com a face posterior do fígado (HAM et al., 1972).

Os hepatócitos estão radialmente dispostos no conceito de lóbulo hepático clássico, baseado no fluxo sanguíneo, da periferia para a veia central situada no centro do lóbulo. As células hepáticas se dispõem em traves ou trabéculas que se arrumam de forma radiada em torno da veia centrolobular. Essas células se anastomosam livremente formando uma espécie de labirinto 
OLIVEIRA, F.R., MACHADO, F.M.E. e COELHO, H.E. Estudo anatomopatológico de fígados que levam a condenação total de carcaça, na linha de inspeção, durante o abate de frangos de corte (Gallus gallus domesticus) na região do Triângulo Mineiro. PUBVET, Londrina, V. 8, N. 2, Ed. 251, Art. 1662, Janeiro, 2014.

semelhante a uma esponja. Os espaços entre essas placas contêm capilares chamados sinusóides hepáticos, que são vasos irregulares compostos por uma camada descontínua de células epiteliais fenestradas. Dessa maneira, partículas com menos de meio micrômetros de diâmetro, pode deixar a luz do sinusóide com relativa facilidade. Macrófagos fixos, denominados de células de Kupffer, estão associados ás células de revestimento endotelial dos sinusóides e suas principais funções são: metabolizar eritrócitos velhos, digerir hemoglobina, secretar proteínas relacionadas com processos imunológicos e destruir bactérias que eventualmente penetrem no sangue portal através do intestino grosso (HAM et al., 1972; JUNQUEIRA; CARNEIRO, 2008).

Um cordão hepático deve ter pelo menos a extensão de duas células, dipostas de tal maneira que possa existir entre as suas membranas justapostas distribuídas em duas camadas, uma luz semelhante a um sulco, denominada canalículo biliar, justificando desse modo, o nome de cordão. Assim, os cordões hepáticos devem ter pelo menos uma distância e espessura de duas células, se funcionarem como unidades secretoras exócrinas. A bile é drenada em direção á periferia do lóbulo onde é esvaziada para pequenos canais e canalículos biliares presentes no sistema porta. Portanto, é transportada das porções centrais dos lóbulos em direção a sua periferia. O sangue por outro lado, é esvaziado nos sinusóides hepáticos, através de ramos tanto da veia porta, como da artéria hepática, na periferia dos lóbulos e é drenado daí para a veia central dos mesmos. Assim, de modo geral, a bile e o sangue correm em direções opostas dentro dos lóbulos (HAM et. al., 1972).

Além do fígado ser um órgão grande, bilobado, também possui muitas funções, dentre as quais a produção da bile, que é armazenada na vesícula biliar e conduzida para o duodeno através do ducto biliar. Ela é constituída por ácidos biliares (ácido chenodeoxicólico, cólico e alcoólico), sais biliares (glicocolato, taurocolato), pigmentos (biliverdina e bilirrubina) e, em aves com mais de 8 semanas, amilase. A função da bile é auxiliar na absorção das gorduras devido á sua ação emulsificante e seus efeitos ativadores sobre a 
OLIVEIRA, F.R., MACHADO, F.M.E. e COELHO, H.E. Estudo anatomopatológico de fígados que levam a condenação total de carcaça, na linha de inspeção, durante o abate de frangos de corte (Gallus gallus domesticus) na região do Triângulo Mineiro. PUBVET, Londrina, V. 8, N. 2, Ed. 251, Art. 1662, Janeiro, 2014.

lipase pancreática, e na digestão dos carboidratos, devido á presença de amilase. Os hepatócitos, pelo fato de entrarem em contato íntimo com o sangue rico em alimentos, conseguem realizar ainda, funções como: reserva, retirando glicose do sangue e armazenando sob a forma de glicogênio. Podem retiram os aminoácidos do sangue e fabricar proteínas, assim, de certa forma, também podem armazenar proteínas. Além disso, armazenam gorduras e algumas das vitaminas, como por exemplo, as vitaminas A e B12. Outra função são as transformações e conjugações, podendo assim transformar várias substâncias originariamente absorvidas pelo intestino em outras que organismo está em deficiência, como por exemplo, as gorduras absorvidas pelo intestino que sob a forma de minúsculas gotículas, denominadas quilomícrons, é transformada na superfície dos hepatócitos, e neles elaborados os produtos alguns dos quais, combinam com a colina e o fósforo para formar fosfolipídeos, extremamente úteis, componentes essenciais das membranas celulares. Se os sinusóides não fossem porosos suficientemente para permitir que o plasma entrasse em contato com os hepatócitos, os quilomícrons não poderiam alcançar diretamente a superfície dos hepatócitos. Outra função que envolve transformação e /ou conjugação é a desintoxicação de certos produtos indesejáveis, absorvidos pelo intestino ou formados no organismo, que poderiam de outra forma, exercer um efeito prejudicial, exemplo da amônia, que é formada no metabolismo dos aminoácidos, é tóxica em certas concentrações; os hepátocitos evitam que essas concentrações sejam atingidas usando-a na formação de substâncias ultilizáveis ou então uréia, que não é tóxica, a não ser em concentrações excessivas. É eliminada do sangue através dos rins. Síntese é outra função dos hepatócitos, produzindo grande quantidade de proteína sanguínea, como albumina, fibrinogênio e a maior parte das globulinas sanguíneas, assim como outras proteínas relacionadas com a coagulação. Se o plasma não entrasse em contato direto com os hepatócitos, as proteínas sanguíneas segregadas por essas células não penetrariam no sangue prontamente. $E$ por último, a regulação da 
OLIVEIRA, F.R., MACHADO, F.M.E. e COELHO, H.E. Estudo anatomopatológico de fígados que levam a condenação total de carcaça, na linha de inspeção, durante o abate de frangos de corte (Gallus gallus domesticus) na região do Triângulo Mineiro. PUBVET, Londrina, V. 8, N. 2, Ed. 251, Art. 1662, Janeiro, 2014.

concentração de certas substâncias no sangue, realizando um controle delicado sobre o nível de açúcar sanguíneo. Ainda que as células hepáticas controlem o nível de muitas substâncias no sangue, é pelo fato de levarem o açúcar ao sangue que o fígado foi primariamente designado como uma glândula endócrina (HAM et. al., 1972; ITO et al., 2000).

O fígado no entanto, é considerado o guardião nutricional do corpo, portanto fatores infecciosos podem interferir com sua função geral. Dentre as afecções que o fígado pode sofrer, destacam-se: neoplasias ou tumores, devido á doença de Marek, leucose linfóide e reticuloendoteliose; hepatites bacterianas, particularmente Clostridium SP. e Salmonlla SP. podem induzir colangite, razão esta que notamos excreção de fezes hipercólicas ou esteatorréicas. Enterotoxemia por Cloristridium perfringens ou mesmo botulismo podem induzir retenção biliar, assim como casos de septicemias bacterianas ( $E$. coli, campilobacteriose ou hepatite vibriônica, etc.); hepatites virais são mais raras, porém no caso de hepatite por corpúsculo de inclusão, podemos notar esteatorréia e o comprometimento do fígado, pâncreas e intestino (ITO et al., 2000).

Assim sendo, o fígado das aves, assim como de outras espécies, pode modificar seu aspecto macroscópico alterando a consistência, a coloração e tamanho, em decorrência da ação de fatores químicos e microbiológicos diretamente em seu parênquima (MACLACHLAN; CULLEN, 1998).

\subsection{INSPEÇÃO}

Segundo Amorim Neto e Miranda (2009), o abate e processamento de carcaças de aves abrangem dentre outras atividades, o controle dentro do abatedouro, sendo estes realizados desde o momento que as aves chegam à plataforma de recepção, até a obtenção do produto final.

A fiscalização e controle da sanidade em aves no Brasil baseiam-se em normas federais, que utilizam parâmetros macroscópicos para avaliar as carcaças dos animais para o consumo humano (BRASIL, 1998). Assim os 
OLIVEIRA, F.R., MACHADO, F.M.E. e COELHO, H.E. Estudo anatomopatológico de fígados que levam a condenação total de carcaça, na linha de inspeção, durante o abate de frangos de corte (Gallus gallus domesticus) na região do Triângulo Mineiro. PUBVET, Londrina, V. 8, N. 2, Ed. 251, Art. 1662, Janeiro, 2014.

fiscais agropecuários avaliam, prioritariamente, aspectos visuais das carcaças nas linhas de produção dos matadouros avícolas, utilizando alguns órgãos como parâmetros para essas avaliações (SILVA et al., 2012).

Os fiscais sanitários removem as carcaças da linha de abate quando estas apresentam qualquer sinal de doença ou outra condição que afete a aparência das mesmas. Dependendo da lesão, os inspetores procedem a uma condenação parcial ou total das carcaças afetadas. A inspeção sanitária é compulsória e legalizada no Brasil desde 1950. Assim, as causas de condenação podem ser de origem infecciosa ou não (PONTES, 2004).

Segundo Amorim Neto e Miranda (2009), as carcaças passam por três linhas de inspeção. Na primeira, a linha A, é feita a inspeção interna da carcaça. É onde se realiza os exames internos das aves, através da visualização da cavidade toráxica e abdominal (celomática) e dos órgãos a ela pertencentes, como sacos aéreos, pulmões, rins e órgãos sexuais. Nesta linha, são retiradas as carcaças com problemas sanitários passíveis de condenação e são encaminhadas para o DIF (Departamento de Inspeção Final), para que sejam feitos os cortes e as condenações totais ou parciais. As vísceras das carcaças que são encaminhadas ao DIF, são retiradas e condenadas. As carcaças que não apresentam problemas para serem encaminhadas ao DIF continuam seguindo pela nória, e então passam pela linha $B$, onde é feita a inspeção das vísceras. É visualizado o coração, fígado, moela, baço, intestinos, ovário e ovidutos nas poedeiras, além de palpação, conforme o caso, verificação de odores e ainda incisão. Na execução do exame em questão, deve ser respeitado o tempo mínimo de 2 (dois) segundos por aves. Quando apresentam problemas, as vísceras então são condenadas e colocadas em chutes, que as encaminham até a fábrica de subprodutos. A última linha de inspeção é a linha $C$, onde é feito o exame externo das carcaças e retiradas fraturas, contusões, e demais lesões que eventualmente tenham passado pelas linhas A e B sem serem retiradas. Todo o trabalho nas linhas de inspeção também é feito por auxiliares de inspeção, disponibilizados pela empresa e 
OLIVEIRA, F.R., MACHADO, F.M.E. e COELHO, H.E. Estudo anatomopatológico de fígados que levam a condenação total de carcaça, na linha de inspeção, durante o abate de frangos de corte (Gallus gallus domesticus) na região do Triângulo Mineiro. PUBVET, Londrina, V. 8, N. 2, Ed. 251, Art. 1662, Janeiro, 2014.

devidamente treinados pelos médicos veterinários oficiais do SIF, sendo que esses auxiliares devem utilizar uniforme diferenciado dos demais colaboradores da indústria. Esses auxiliares de inspeção são fiscalizados constantemente pelos médicos veterinários, oficiais fiscais encarregados pelo estabelecimento e pelos agentes de inspeção, também do SIF.

Portanto, o fígado é inspecionado na linha B de abate e os critérios de condenação de vísceras de frangos, especialmente de fígados, consideram o aspecto visual (cor, forma e tamanho), consistência e odor do órgão, de acordo com Brasil (1998). Randall e Reece (1996) afirmam que o conhecimento das características do órgão é fundamental para a correta avaliação sanitária das carnes de aves. Muitas lesões do fígado, não são específicas, assim como as causas das mesmas, porém elas proporcionam uma importante informação sobre os diversos processos patológicos e, em muitas espécies de aves, é o primeiro e maior órgão interno a ser visto na necropsia, quando a cavidade corporal é aberta.

Utilizando os critérios de julgamento, é possível chegar ás decisões sanitárias das carnes destinadas ao consumo humano, que de acordo com a legislação brasileira são: aprovação total, aprovação com restrições ou sob condições, condenação parcial e a condenação total (BRASIL, 1998).

De acordo com Silva et al. (2012), dentre as causas que determinam a apreensão das aves e posterior condenação da carcaça, destacam-se aerossaculite, caquexia, septicemia, síndrome ascítica e colibacilose.

Com o advento da avicultura moderna industrial, que tem como modelo de criação quase que exclusivamente o confinamento, as patologias aviárias se incrementam e a Escherichia coli, assim como outros agentes, neste tipo de atividade, aparece com frequência causando perdas e enormes prejuízos econômicos (SILVA, 1992). 
OLIVEIRA, F.R., MACHADO, F.M.E. e COELHO, H.E. Estudo anatomopatológico de fígados que levam a condenação total de carcaça, na linha de inspeção, durante o abate de frangos de corte (Gallus gallus domesticus) na região do Triângulo Mineiro. PUBVET, Londrina, V. 8, N. 2, Ed. 251, Art. 1662, Janeiro, 2014.

\subsection{SALMONELOSE}

Atualmente as salmoneloses ocupam uma das posições mais destacadas no campo da saúde pública em todo o mundo, pois apesar de todo o desenvolvimento tecnológico e da adoção de melhores medidas de higiene, é crescente e relevante o número de casos de salmonelose humana e animal. Nas criações industriais, as doenças de maior importância econômica e sanitária são a pulorose causada pela S. pullorum, o tifo aviário causado pela S. gallinarum e o paratifo causado pelas salmonelas denominadas paratifóides, principalmente pela S. enteritidis (SE) e S. thyphimurium (Sth) (PENHA et al., 2008).

Segundo Ferreira et al. (1990), o primeiro relato da ocorrência de Salmonella enteriditis (SE) em aves foi realizado por pesquisadores da USP em 1990. Até então, a identificação de Se pelos dois principais centros de sorotipagem de salmonelas do país era muito baixa.

Segundo Coelho (2006), a salmonelose aviária é uma doença septicêmica que acomete aves domésticas; sendo esta caracterizada por esplenomegalia, hepatomegalia e diarréia. Tem sua causa na Salmonella gallinarum, transmitida por meio de ovos e aves contaminadas.

Os sorovares de Salmonella mais comuns em fontes humanas e não humanas são: Anatum, Typhimurium, Derby, Agona, Infantis, Havana, Cerro, Livingstone e Enteriditis (SILVA; DUARTE, 2002).

A salmonelose é a enfermidade transmitida por alimentos que se apresenta com maior frequência há muitos anos em todo o mundo. A doença atinge o homem e praticamente todos os animais, e têm sido verificada a elevação de sua frequência, sobretudo nos últimos 10 anos, em virtude do aumento de infecções por Samonella enteritidis, principalmente nos países desenvolvidos (ARRUDA, 2000). É um problema mundialmente persistente e leva a dificuldades comerciais, prejuízos econômicos e queda na produção. A redução da sua presença é crítica em abatedouros e no processamento de produtos aviários como ovos, carne e derivados (BARCELOS, 2005). 
OLIVEIRA, F.R., MACHADO, F.M.E. e COELHO, H.E. Estudo anatomopatológico de fígados que levam a condenação total de carcaça, na linha de inspeção, durante o abate de frangos de corte (Gallus gallus domesticus) na região do Triângulo Mineiro. PUBVET, Londrina, V. 8, N. 2, Ed. 251, Art. 1662, Janeiro, 2014.

De acordo com Hoerr (1996), Salmonella pullorum e Salmonella enteritidis são as espécies mais patogênicas em frangos, causando severas lesões. Na necropsia, as lesões características compreendem: tiflite, hepatite, esplenite, miocardite, ventriculite e artrite. Segundo o mesmo autor, o fígado apresenta-se aumentado de volume e congesto, pálido e brilhante, com aspecto bronzeado comumente acompanhado de pequenos focos brancos. A progressão histológica no fígado assemelha-se a outras infecções bacterianas agudas, mas com zonas de necrose multifocais a coalescentes dos hepatócitos acompanhadas por inflamação linfocítica.

Gast (2003) cita que há uma quantidade limitada de informações sobre os achados microscópicos de tifo e pulorose, pois os relatos, em sua maioria, são de achados de campo, os quais podem estar associados e/ou complicados por outras bactérias ou agentes virais. Entretanto, o autor acrescenta que, embora as lesões sejam bastante diversas, achados microscópicos de necrose multifocal dos hepatócitos com acúmulo de fibrina e infiltração heterofílica no parênquima hepático podem ser vistas em casos agudos.

$\mathrm{Na}$ fase crônica da infecção, é possível observar esplenomegalia, hepatomegalia apresentando coloração esverdeada, amarronzada ou mesmo bronzeada, salpicado de pontos acinzentados milimétricos, pericardite, peritonite, rupturas e má-formação de ovos (COELHO, 2006).

Barcelos et al. (2006), não observaram lesões microscópicas em fígados, que pudessem ser indicativas de infecção por Salmonella spp. As infecções por bactérias do gênero Salmonella podem lembrar outras infecções bacterianas agudas, porém apresentam como características áreas multifocais a coalescentes de necrose de hepatócitos acompanhadas de inflamação linfocítica. Inflamação linfocítica multifocal permanece como uma sequela da necrose induzida por Salmonella spp., embora isto não seja específico. Aglomerados de bastonetes podem ser observados em seções histológicas de fígados durante a infecção por Salmonella enteritidis (RANDALL; REECE, 1996). 
OLIVEIRA, F.R., MACHADO, F.M.E. e COELHO, H.E. Estudo anatomopatológico de fígados que levam a condenação total de carcaça, na linha de inspeção, durante o abate de frangos de corte (Gallus gallus domesticus) na região do Triângulo Mineiro. PUBVET, Londrina, V. 8, N. 2, Ed. 251, Art. 1662, Janeiro, 2014.

Salmonelas foram isoladas em $9 / 36$ pools de fígados de frangos condenados pelo SIF em um abatedouro do estado de Goiás, sendo em sete, isolamento de Salmonella enteritidis e em dois, Salmonella typhimurium (OLIVEIRA, 2004).

\subsection{COLIBACILOSE}

A colibacilose é uma enfermidade infecciosa que acomete primariamente aves jovens, caracterizada por septicemia, aerossaculite, peritonite, onfaloflebite e granuloma hepático. É provocada pela Escherichia coli, bactéria gram negativa, habitante comum do trato intestinal das aves e demais espécies (COELHO, 2006).

A E. coli foi descrita pela primeira vez em 1885 por Theodor von Escherich e denominada Bacterium coli commune (FERREIRA; KNOLB, 2000).

A colibacilose é considerada multifatorial. O aparecimento desta depende da interação entre muitas variáveis, como: microrganismo, manejo, alimentação, instalações e condição da ave. Os vários fatores predisponentes à colibacilose são as infecções por Mycoplasma spp (MOORHEAD; SAIF, 1970), vírus da bronquite infecciosa e da doença de Newcastle (GROSS, 1961), além das doenças supressoras (NAKAMURA, 1990), ventilação inadequada, estresse, superpopulação e excesso de poeiras e gases (NAGARAJA, 1993).

A colibacilose é uma das principais doenças da avicultura industrial moderna, em função dos grandes prejuízos econômicos causados no mundo inteiro (FERREIRA; KNÖBL, 2000).

Assim, as perdas econômicas são elevadas, com extensão por toda vida da ave. Os pintinhos acometidos apresentam um desenvolvimento deficiente ou se tornam aves portadoras, susceptíveis a várias enfermidades (FERREIRA; KNÖBL, 2000).

Segundo Yoder, Beard e Mitchell (1989), Lang (1992) e Gross (1994), de modo geral, qualquer fator ambiental, nutricional ou infeccioso, assim como 
OLIVEIRA, F.R., MACHADO, F.M.E. e COELHO, H.E. Estudo anatomopatológico de fígados que levam a condenação total de carcaça, na linha de inspeção, durante o abate de frangos de corte (Gallus gallus domesticus) na região do Triângulo Mineiro. PUBVET, Londrina, V. 8, N. 2, Ed. 251, Art. 1662, Janeiro, 2014.

aqueles que interferem no bom funcionamento do sistema imunológico, podem tornar a ave susceptível à infecção por E. Coli patogênica das aves (APEC).

Os sacos aéreos tornam-se espessos com presença de exsudato caseoso. Microscopicamente, as alterações são devido à presença de edema e infiltrado heterofílico, com macrófagos e células gigantes circundando o tecido necrosado (ROSA et al., 1992).

Segundo Coelho (2006), clinicamente as aves apresentam, dependendo da forma da doença, depressão, apatia, diarreia e dificuldade respiratória. Macroscopicamente são observadas hemorragias na pele, em forma de manchas avermelhadas. Nos músculos, no peritônio visceral, no coração e no tecido adiposo, as hemorragias aparecem principalmente na forma aguda da doença. Já na forma crônica, a doença é conhecida como coligranuloma. O destaque vai para a formação de nódulos centimétricos de coloração amarelada ou branca, espalhados por toda a cavidade, comprometendo fígado, intestino, rins e demais vísceras. O coligranuloma, macroscopicamente, pode ser confundido com os diferentes tipos de linfoma das aves.

Silva et al. (2012), em um trabalho feito em matadouros avícolas, onde foram colhidas 62 amostras de fígados de frango, das quais $30 \mathrm{com}$ aspecto macroscópico inalterado e 32 com alteração macroscópica, que originou o descarte da carcaça pela inspeção da linha B., Escherichia coli foi isolada em $45,5 \%$ dos fígados coletados. A colangio-hepatite foi a alteração inflamatória predominante e considerada multifocal, onde detectou-se a predominância de heterófilos e mononucleares.

Esses dados corroboram com os achados de Barcelos et al. (2006) e Dey et al. (2003), que também observaram com maior incidência a colangiohepatite heterofílica multifocal, seguida de hepatite necrosante aleatória como achado microscópico associado ao isolamento de Escherichia coli. A presença de infiltrados mistos, especialmente heterófilos e linfócitos, associados à presença de Escherichia coli também foram encontrados por Haider et al. (2004). 
OLIVEIRA, F.R., MACHADO, F.M.E. e COELHO, H.E. Estudo anatomopatológico de fígados que levam a condenação total de carcaça, na linha de inspeção, durante o abate de frangos de corte (Gallus gallus domesticus) na região do Triângulo Mineiro. PUBVET, Londrina, V. 8, N. 2, Ed. 251, Art. 1662, Janeiro, 2014.

Lovland e Kaldhusdal (2001) encontraram dados semelhantes em amostras de fígados de frangos rejeitados no matadouro. A congestão foi considerada discreta em 12/27 fígados, seguida de moderada (9/27) e acentuada (6/27). A hemorragia foi observada em 3/27 amostras e necrose em 7/27. A fibrose periportal ocorreu em 6/27 amostras e a hiperplasia dos ductos biliares em 9/27. Foram observados microabscessos em 9/27 amostras e 2/27 das amostras apresentavam esteatose.

\subsection{DOENÇA DE MAREK}

De acordo com Coelho (2006), a doença de Marek é uma enfermidade infecciosa caracterizada pela formação de tumores nos nervos, pele, baço, fígado, rim, ovários, testículos, olhos e demais vísceras. Causada por um herpes-vírus, da família herpesviridae, com três sorotipos: o oncovírus (sorotipo 1); o não oncogênico (sorotipo 2); e o herpes-vírus do peru (sorotipo 3).

A galinha é o principal hospedeiro em condições naturais. A doença de Marek é encontrada onde se pratica a avicultura intensiva e é a mais importante neoplasia das aves. Ela foi descrita pela primeira vez, em 1907, na Hungria, por Marek, que a denominou de polineurite; em 1926, foi considerada de natureza neoplásica. Depois disso, várias informações sobre a doença foram se espalhando no mundo e, em 1961, por ocasião da reunião da World's Poultry Association, recebeu o nome definitivo de doença de Marek, diferenciando-se as duas principais formas de apresentação (1) clássica, com lesões neurais e; (2) aguda, com lesões tumorais nas vísceras (SANTOS et al., 2008).

Tumores linfóides podem ocorrer em qualquer local, mas principalmente no fígado, baço, rins, coração, mesentério, gônadas, pulmões, bolsa cloacal, timo, glândula adrenal, proventrículo, pâncreas, intestino, pele, músculos esqueléticos e íris. A cepa do vírus e a linhagem do hospedeiro influenciam na localização das lesões. Tumores viscerais são mais comuns nas formas agudas 
OLIVEIRA, F.R., MACHADO, F.M.E. e COELHO, H.E. Estudo anatomopatológico de fígados que levam a condenação total de carcaça, na linha de inspeção, durante o abate de frangos de corte (Gallus gallus domesticus) na região do Triângulo Mineiro. PUBVET, Londrina, V. 8, N. 2, Ed. 251, Art. 1662, Janeiro, 2014.

da doença e podem ser encontrados na ausência de lesões nervosas macroscópicas. As lesões macroscópicas na íris vão desde a despigmentação até irregularidades na pupila. Ambas são o resultado da infiltração de células mononucleares na íris (CANAL; SILVA, 2000).

Segundo Coelho (2006), macroscopicamente o nervo ciático e o vago correm o risco de estar afetados com espessamento e aumento das estriações e mudança de coloração, exibindo um tom cinza ou amarelado. Segundo a localização das lesões, podemos classificar a doença de Marek em três formas: visceral, cutânea e nervosa ou neurolinfomatose (atingindo os nervos e olhos).

Pela necropsia, observam-se tumores macios, brilhantes e lisos. A superfície de corte é cremosa e de cor acinzentada ou brancacenta. Esses tumores podem ser nodulares, miliares ou difusos, e suas dimensões variam do tamanho de uma cabeça de alfinete a de um ovo de galinha. Com o tumor difuso, o órgão apresenta aumento de volume uniforme e cor levemente acinzentada, além de tornar-se muito friável (SANTOS et al., 2008).

Microscopicamente, o vírus atinge os linfócitos, que se tornam neoplásicos, e exibe um grande pleomorfismo: são observados linfócitos de várias formas. Eles são grandes e hipercromáticos, com o núcleo proeminente. Essa característica permite a diferenciação com relação a leucose, que apresenta uniformidade celular (COELHO, 2006).

Com relação à idade, esta última ocorre entre os 5 e os 9 meses de idade, contrariamente à primeira que ocorre por volta da $6^{\mathrm{a}}$ semana de vida (BEYER et al., 1980; PAYNE, 1993). Por outro lado, a bolsa cloacal, normalmente, apresenta-se apenas atrofiada, raramente desenvolvendo tumores, contrariamente ao que acontece no caso da leucose (BEYER et al., 1980; FADLY; CRITTENDEN, 1987; CALNEK, 1997).

Segundo Calnek (1997), as aves com doença de Marek podem apresentar sinais não específicos tais como perda de peso, palidez, anorexia e diarréia e, se estes animais forem sujeitos durante algum período a uma má nutrição, podem evidenciar caquexia. 
OLIVEIRA, F.R., MACHADO, F.M.E. e COELHO, H.E. Estudo anatomopatológico de fígados que levam a condenação total de carcaça, na linha de inspeção, durante o abate de frangos de corte (Gallus gallus domesticus) na região do Triângulo Mineiro. PUBVET, Londrina, V. 8, N. 2, Ed. 251, Art. 1662, Janeiro, 2014.

De acordo com o trabalho de Pinto et al. (2003), na necropsia de três aves, rejeitadas no exame post mortem pela presença de caquexia $(n=2)$ e de traumatismos ( $n=1)$, evidenciou-se a presença de lesões compatíveis com a doença de Marek. Os três casos detectados neste trabalho, apresentavam a forma visceral da doença, evidenciando uma hepato e esplenomegalia com infiltrados de um tecido de cor esbranquiçada compatível com lesão neoplásica. Os tumores viscerais são especialmente comuns em formas agudas da doença e podem ser encontrados sem haver lesão dos nervos e sem sintomatologia, razão pela qual podem passar despercebidos na produção e no exame ante mortem (DORN, 1973; POWELL; PAYNE, 1993; RITCHIE, 1995; CALNEK, 1997).

Segundo Fadly e Crittenden (1987) e Calnek (1997) apenas uma pequena porcentagem de frangos infectados desenvolvem a doença clínica, o que pode comprometer o diagnóstico da doença em vida.

\subsection{LEUCOSE AVIÁRIA}

Leucose aviária é uma doença infectocontagiosa causada por retrovírus, da família Retroviridae e que induz a formação de tumores em galinhas e em outras espécies aviárias. O vírus da leucose aviária foi dividido em seis subgrupos ( $A, B, C, D, E$ e J), classificado pelo mecanismo natural de transmissão em vírus endógeno e exógeno, sendo os vírus exógenos ( $A, B$ e J) os de maior impacto econômico, pois se disseminam de forma vertical e horizontal, levando ao desenvolvimento de neoplasias, enquanto os subgrupos exógenos ( $C$ e $D$ ) e o subgrupo endógeno (E) são considerados não patogênicos (COELHO, 2006).

Os subgrupos F, G, H e I, têm sido isolados de faisões, codornas e perdizes (CANAL; SILVA, 2000).

Os vírus da família Retroviridae são caracterizados por exclusivo método de reprodução. A replicação viral é caracterizada pela formação de um provírus DNA sob a direção da enzima transcriptase reversa, que integra-se ao DNA da 
OLIVEIRA, F.R., MACHADO, F.M.E. e COELHO, H.E. Estudo anatomopatológico de fígados que levam a condenação total de carcaça, na linha de inspeção, durante o abate de frangos de corte (Gallus gallus domesticus) na região do Triângulo Mineiro. PUBVET, Londrina, V. 8, N. 2, Ed. 251, Art. 1662, Janeiro, 2014.

célula hospedeira. Isto possibilita a transcrição do RNA viral, o qual é traduzido para produzir as proteínas virais que constituem o virión (ITO, 1999).

Segundo Back (2002), a leucose linfóide (LA) é uma doença neoplásica viral que induz a formação de tumores na bolsa cloacal podendo ocasionar metástase em outros órgãos. O termo leucose refere-se à ocorrência de infecção em leucócitos e é popularmente utilizado para denominar neoplasias ou tumores nestas células.

Nos últimos anos, foram obtidas linhagens de aves resistentes aos subgrupos A e $B$, mas levarão alguns anos para se conseguirem plantéis completamente livres do vírus do subgrupo J. Esse subgrupo é o responsável pela leucose mielóide. Os demais subgrupos patogêncios são responsáveis pela leucose linfóide (COELHO, 2006).

Segundo Payne (1998), a leucose mielóide manifesta-se comumente em aves de linhagem pesada e com idade acima de 17 semanas (inicio da maturidade sexual).

O vírus da leucose aviária subgrupo J (VLA-J), foi diagnosticado primeiramente na Inglaterra em 1989 e nos últimos anos têm sido identificado em plantéis avícolas em muitas regiões do mundo. Nos Estados Unidos constatou-se uma grande incidência desse vírus em lotes de reprodutores de linhagem pesada, conforme relata Fadly e Smith (1999), e no Brasil, a ocorrência de VLA-J também tem sido relatada. A transmissão horizontal ocorre por contato direto de ave a outras através de excreções e secreções, geralmente há produção de anticorpos e o aparecimento de tumores é raro (PAYNE, 1998).

Alguns autores afirmam que na leucose mielóide, as células neoplásicas são originadas a partir da linhagem mielomonocítica na fase final de diferenciação (PAYNE, 1998). Outros postulam que a origem pode estar em mieloblastos (JORDAN; PATTISON, 1996). Uma inoculação experimental do vírus em uma cultura de células da medula óssea mostrou que as células 
OLIVEIRA, F.R., MACHADO, F.M.E. e COELHO, H.E. Estudo anatomopatológico de fígados que levam a condenação total de carcaça, na linha de inspeção, durante o abate de frangos de corte (Gallus gallus domesticus) na região do Triângulo Mineiro. PUBVET, Londrina, V. 8, N. 2, Ed. 251, Art. 1662, Janeiro, 2014.

tinham transformado características morfológicas sugestivas de precursoras de macrófagos (PAYNE, 1993).

O vírus transforma células mielomonocíticas no estágio final de diferenciação, mielócito ou monócito (PAYNE, 1998).

Células infectadas são transformadas gradualmente em células neoplásicas, as quais migram para colonizar outros órgãos, produzindo tumores de diversos tipos (PAYNE; FADLY, 1997).

$\mathrm{Na}$ leucose mielóide, as células mielóides são transformadas e permanecem latentes até a maturidade sexual da ave (16 a 22 semanas), quando a divisão celular se inicia e adquire características neoplásicas, disseminando-se para a superfície dos ossos, particularmente junções costocondrais, costelas, esterno, vértebras, pélvis e, infiltração em órgãos viscerais principalmente fígado, baço, rins, ovário, mesentério, pulmões, traquéia e laringe. O mecanismo molecular para indução da doença, de ocorrência natural, ainda não é bem conhecido (ITO, 1999).

As lesões macroscópicas da leucose mielóide são tumores de coloração branco-amarelada, nodulares ou difusos, encontrados no esterno, fígado e costelas, algumas vezes acometendo o baço, rins, timo e gônadas (PAYNE, 1998).

Foi observado, em galinhas com leucose mielóide, células tumorais na medula óssea de vários ossos (cabeça, costela, vértebras, esterno, fêmur, úmero) e nas partes ossificadas da cartilagem da laringe e traquéia. No esterno, os mielócitos acumularam no periósteo e nos músculos adjacentes (FADLY; SMITH, 1999).

As lesões mais comuns da leucose mielóide são: múltiplos focos puntiformes de coloração esbranquiçada, distribuídos difusamente pelo parênquima hepático, esplênico, renal e no ovariano. Foram relatados casos de tumores em timo, cloaca, ovário, pâncreas, mesentério e músculo peitoral, em que a lesão assumiu aspecto nodular $e$ as formações tumorais não ultrapassaram $0,5 \mathrm{~cm}$ de diâmetro. Também verificou-se na glândula da 
OLIVEIRA, F.R., MACHADO, F.M.E. e COELHO, H.E. Estudo anatomopatológico de fígados que levam a condenação total de carcaça, na linha de inspeção, durante o abate de frangos de corte (Gallus gallus domesticus) na região do Triângulo Mineiro. PUBVET, Londrina, V. 8, N. 2, Ed. 251, Art. 1662, Janeiro, 2014.

membrana nictante, acentuado aumento de volume, superfície irregular, coloração branca, e na face ventral da pele da região cervical, evidenciou-se a presença de nódulo ulcerado, de consistência firme com $1 \mathrm{~cm}$ de diâmetro (MANZAN, 2000).

O aspecto macroscópico pode fornecer indicações sobre a natureza do tumor, mas a histopatologia é essencial para um diagnóstico adequado (PAYNE; McKAY, 1999). Histologicamente o tumor consiste de uma massa de mielócitos uniformes com pouco estroma, as células tumorais são similares aos mielócitos normais, porém com núcleos grandes, nucléolo evidente e citoplasma preenchido com grânulos acidófilos (PAYNE; FADLY, 1997).

O VLA-J pode interagir com outros vírus causadores de tumor, principalmente com o vírus da doença de Marek (McKAY, 1998; ZAVALA, 1999) por isso o diagnóstico virológico não estabelece por si só a causa do tumor, tornando-se necessário a identificação histopatológica para indicar sua causa provável (PAYNE; McKAY, 1999).

Em 2009, no setor de Ornitopatologia da Faculdade de Medicina Veterinária e Zootecnia de Garça FAMED/FAEF, uma galinha doméstica (Gallus gallus) que constatou-se morte súbita, sem prévia manifestação de nenhum sinal e/ou sintomas clínicos, onde ao exame necroscópico do cadáver, pode ser observado um aumento de volume hepático e congestão e ao exame histopatológico do fígado notou-se desarranjo das trabéculas hepáticas, acentuada infiltração leucocitária neoplásica desorganizada, constatou-se que os achados macroscópicos e histopatológicos observados eram compatíveis com um quadro de Leucose Linfóide (ROCHA et al., 2009).

\section{OBJETIVO}

Analisar macro e microscopicamente, as lesões nos parênquimas de fígados de frangos de corte, que a partir da análise macroscópica na linha de inspeção, determinaram a condenação desta víscera e carcaça correspondente, 
OLIVEIRA, F.R., MACHADO, F.M.E. e COELHO, H.E. Estudo anatomopatológico de fígados que levam a condenação total de carcaça, na linha de inspeção, durante o abate de frangos de corte (Gallus gallus domesticus) na região do Triângulo Mineiro. PUBVET, Londrina, V. 8, N. 2, Ed. 251, Art. 1662, Janeiro, 2014.

visando interpretá-las, no intuito de esclarecimento do tipo de agente etiológico (bacteriano, neoplásico ou viral) envolvido no processo.

\section{MATERIAL E MÉTODO}

Foram colhidos, em um abatedouro localizado na região do Triângulo Mineiro, cem fígados de frango de corte que, a partir de lesões em seu parênquima, condenaram, juntamente com os mesmos, a carcaça na linha de inspeção, e dez fígados aparentemente normais para teste controle. O peso das aves variou de 1,3 a 1,6 kg e idade de 33 dias. Os fígados que eram condenados, apresentavam macroscopicamente: aumento de volume, características friáveis e coloração que variava entre manchas avermelhadas, intercaladas com áreas esverdeadas, amareladas e esbranquiçadas, não permitindo ao inspetor um diagnóstico etiológico seguro compatível com as lesões pertinentes com salmonelose, colibacilose e enfermidades neoplásicas. São várias as causas de condenação em abatedouros, dentre elas, as 3 enfermidades, conforme relata Silva et al. (2012) e Barcelos et al. (2006). Esses achados macroscópicos, foram suficientes para levarem á condenação dos fígados, juntamente com suas carcaças, pelos fiscais, de acordo com o que é preconizado pelo SIF, que considera o aspecto visual (cor, forma e tamanho), a consistência e o odor do órgão. A esses fígados condenados, foi incriminada macroscopicamente pelos fiscais responsáveis, a colibacilose como a principal causa.

O abatedouro o qual foi realizada a coleta, abate cerca de 100.000 aves/dia, sendo que os fígados foram colhidos em 3 visitas de 2 horas cada.

A coleta se deu no período de outubro a novembro de 2012 no abatedouro, sem a interrupção de seu fluxo. Os fígados que apresentavam as alterações acima foram condenados, juntamente com as carcaças e retirados da linha de inspeção. Foram armazenados em um vasilhame de uso próprio do abatedouro, e os mesmos direcionados á sala de necropsia, anexa á sala de 
OLIVEIRA, F.R., MACHADO, F.M.E. e COELHO, H.E. Estudo anatomopatológico de fígados que levam a condenação total de carcaça, na linha de inspeção, durante o abate de frangos de corte (Gallus gallus domesticus) na região do Triângulo Mineiro. PUBVET, Londrina, V. 8, N. 2, Ed. 251, Art. 1662, Janeiro, 2014.

abate, onde foram realizadas a separação da víscera do restante da carcaça, assim como a identificação dos achados macroscópicos que levaram a essa condenação, anotados os mesmos (alterações na cor, forma e tamanho), fotografadas as peças com ajuda de uma máquina digital, fracionados os órgãos, para análise histopatológica e então armazenados em frascos contendo uma solução de água e $10 \%$ de formalina. As amostras foram trazidas para Uberaba, em uma caixa de isopor, e então direcionadas ao Laboratório de Histopatologia da Universidade de Uberaba, Campus Aeroporto, para fabricação das lâminas para estudo histopatológico dos mesmos.

Para a confecção das lâminas histológicas, as frações dos fígados no entanto, foram desidratadas em séries crescentes de alcoóis, diafonizadas em xilol, impregnadas em parafina histológica, cortadas a cinco micrômetros e coradas por hematoxilina eosina (HE), conforme relatado por Luna (1968). Posteriormente foram encaminhadas para exame á luz da microscopia óptica no Laboratório de Patologia, situado na Faculdades Associadas de Uberaba (FAZU).

Após análise das lâminas em microscópico óptico, no aumento de 40X, as lesões foram descritas e agrupadas, de acordo com o tipo de alteração encontrada.

\section{RESULTADOS}

Ao exame dos fígados que foram retirados da linha de inspeção e consequentemente, também condenaram as carcaças, no total de 100 , observou-se: fígados com aumento de volume e bordas arredondadas, friáveis, coloração avermelhada com manchas amarelada, esverdeada e brancacenta, conforme pode ser visto na Tabela 01 e Figuras 1, 2, 3 e 4. A Figura 5 representa fígado aparentemente normal. 
OLIVEIRA, F.R., MACHADO, F.M.E. e COELHO, H.E. Estudo anatomopatológico de fígados que levam a condenação total de carcaça, na linha de inspeção, durante o abate de frangos de corte (Gallus gallus domesticus) na região do Triângulo Mineiro. PUBVET, Londrina, V. 8, N. 2, Ed. 251, Art. 1662, Janeiro, 2014.

Tabela 01: Alterações macroscópicas observadas em fígados de frango de corte, que levaram a sua condenação e de suas respectivas carcaças na linha de inspeção.

\section{Achados macroscópicos}

\section{Quantidade (N) Porcentagem}

(\%)

Aumento de volume com bordas

100

arredondadas

Degeneração turva

100

100

Friáveis

100

100

Hemorragia do tiipo sufusão

35

35

Hiperemia ativa

76

76

Manchas amareladas

25

25

Manchas avermelhadas

35

35

Manchas brancacentas

11

11

Manchas esverdeadas

29

29

Necrose focal disseminada

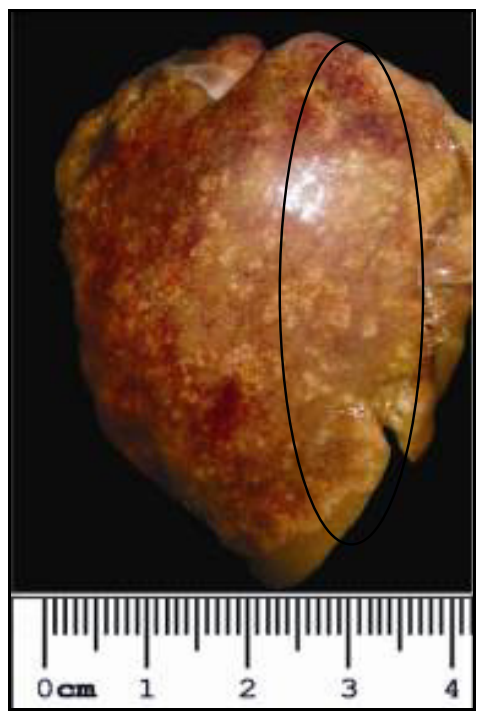

Figura 1: Aspecto macroscópico de fígado de frango de corte com 33 dias de vida, apresentando coloração esverdeada (círculo), com pontos esbranquiçados. 
OLIVEIRA, F.R., MACHADO, F.M.E. e COELHO, H.E. Estudo anatomopatológico de fígados que levam a condenação total de carcaça, na linha de inspeção, durante o abate de frangos de corte (Gallus gallus domesticus) na região do Triângulo Mineiro. PUBVET, Londrina, V. 8, N. 2, Ed. 251, Art. 1662, Janeiro, 2014.

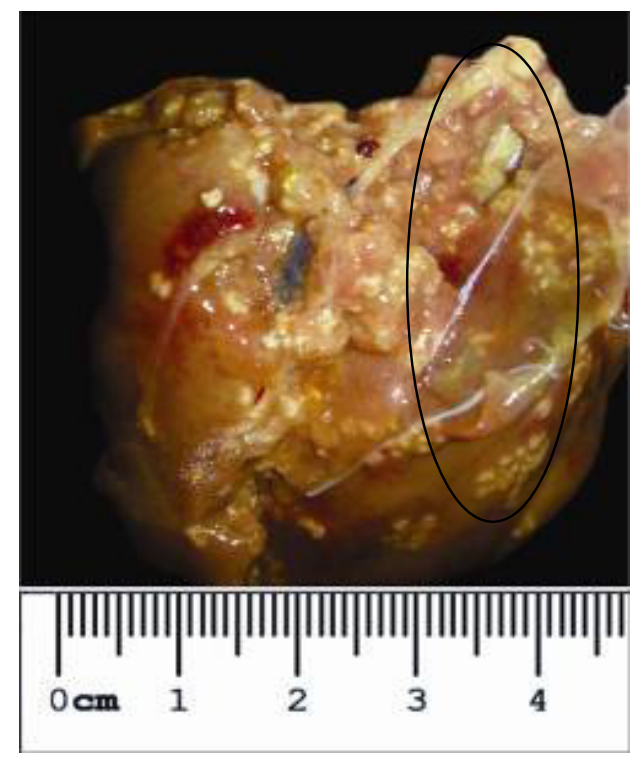

Figura 2: Aspecto macroscópico de fígado de frango de corte com 33 dias de vida, apresentando coloração amarelada (círculo) com manchas esbranquiçadas e aumentado de volume.

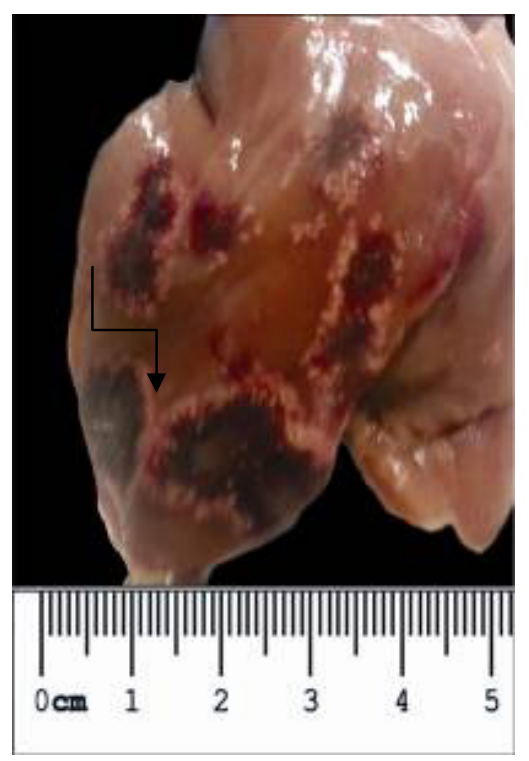

Figura 3: Aspecto macroscópico de fígado de frango de corte com 33 dias de vida, apresentando coloração marmórea, levemente pálido em suas extremidades, com áreas de hemorragia do tipo sufusão (seta). 
OLIVEIRA, F.R., MACHADO, F.M.E. e COELHO, H.E. Estudo anatomopatológico de fígados que levam a condenação total de carcaça, na linha de inspeção, durante o abate de frangos de corte (Gallus gallus domesticus) na região do Triângulo Mineiro. PUBVET, Londrina, V. 8, N. 2, Ed. 251, Art. 1662, Janeiro, 2014.

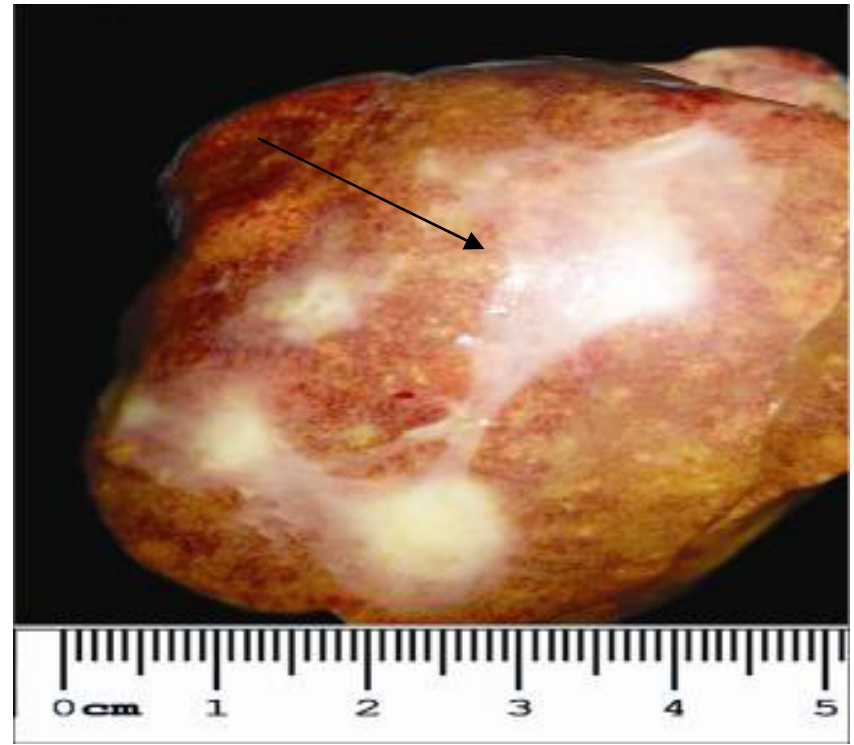

Figura 4: Aspecto macroscópico de fígado de frango de corte com 33 dias de vida, apresentando manchas brancacentas (seta), intercaladas com áreas amareladas.

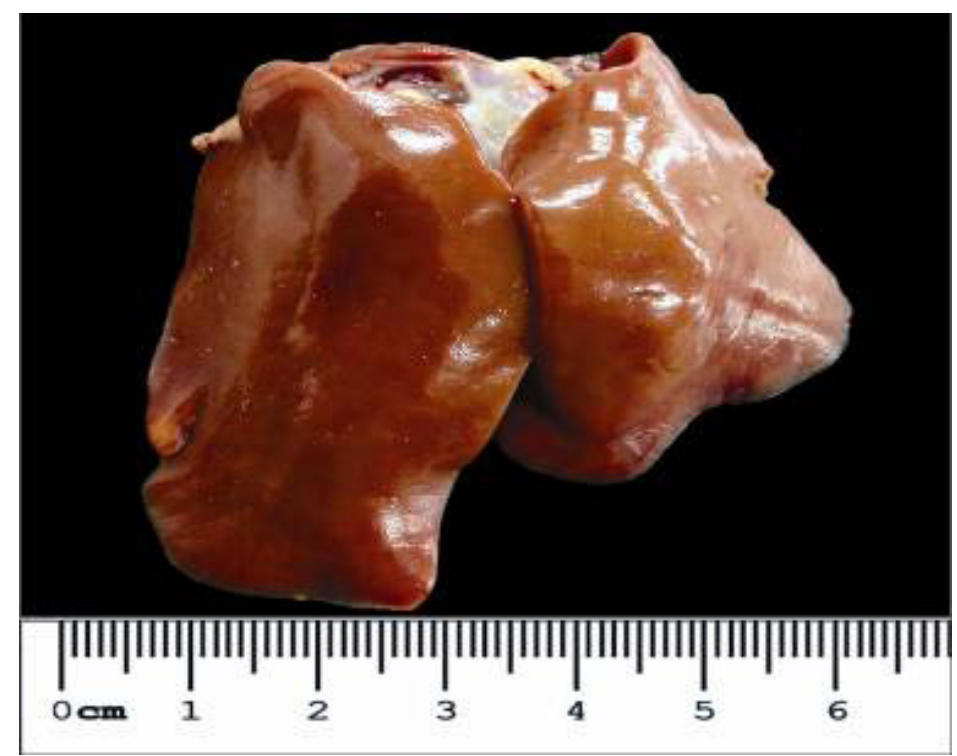

Figura 5: Aspecto macroscópico de fígado de frango de corte, com 33 dias de vida, aparentemente normal. 
OLIVEIRA, F.R., MACHADO, F.M.E. e COELHO, H.E. Estudo anatomopatológico de fígados que levam a condenação total de carcaça, na linha de inspeção, durante o abate de frangos de corte (Gallus gallus domesticus) na região do Triângulo Mineiro. PUBVET, Londrina, V. 8, N. 2, Ed. 251, Art. 1662, Janeiro, 2014.

Os achados microscópicos, sendo o infiltrado heterofílico a principal alteração observada, seguida pelo mesmo achado, porém com áreas de invasão de tecido conjuntivo e fibrina e por último, os grupos de mielócitos, estão exibidos na sua totalidade, na Tabela 02.

Ao exame microscópico, cinquenta e seis por cento (56\%) dos fragmentos analisados apresentaram múltiplos focos inflamatórios, caracterizados pela invasão de heterófilos, que exibiam: núcleos polimórficos bastante evidentes, com citoplasma abundante, repleto de granulações acidófilas, coradas pela eosina em róseo avermelhado, justificando a hepatite heterofílica focal disseminada (FIGURA 6).

Tabela 02: Alterações microscópicas observadas em fígados de frangos de corte, condenados na linha de inspeção.

Achados microscópicos

Degeneração turva

Grupos de Mielócitos

Hemorragia tipo sufusão

Hiperemia ativa

Infiltração de heterófilos, fibrina e

tecido conjuntivo fibroso

Infiltrado Heterofílico

Necrose coagulativa focal disseminada
Quantidade (N)

Porcentagem

(\%)

$\begin{array}{cc}100 & 100 \\ 20 & 20 \\ 35 & 35 \\ 76 & 76 \\ 24 & 24 \\ 56 & 56 \\ 100 & 100\end{array}$


OLIVEIRA, F.R., MACHADO, F.M.E. e COELHO, H.E. Estudo anatomopatológico de fígados que levam a condenação total de carcaça, na linha de inspeção, durante o abate de frangos de corte (Gallus gallus domesticus) na região do Triângulo Mineiro. PUBVET, Londrina, V. 8, N. 2, Ed. 251, Art. 1662, Janeiro, 2014.

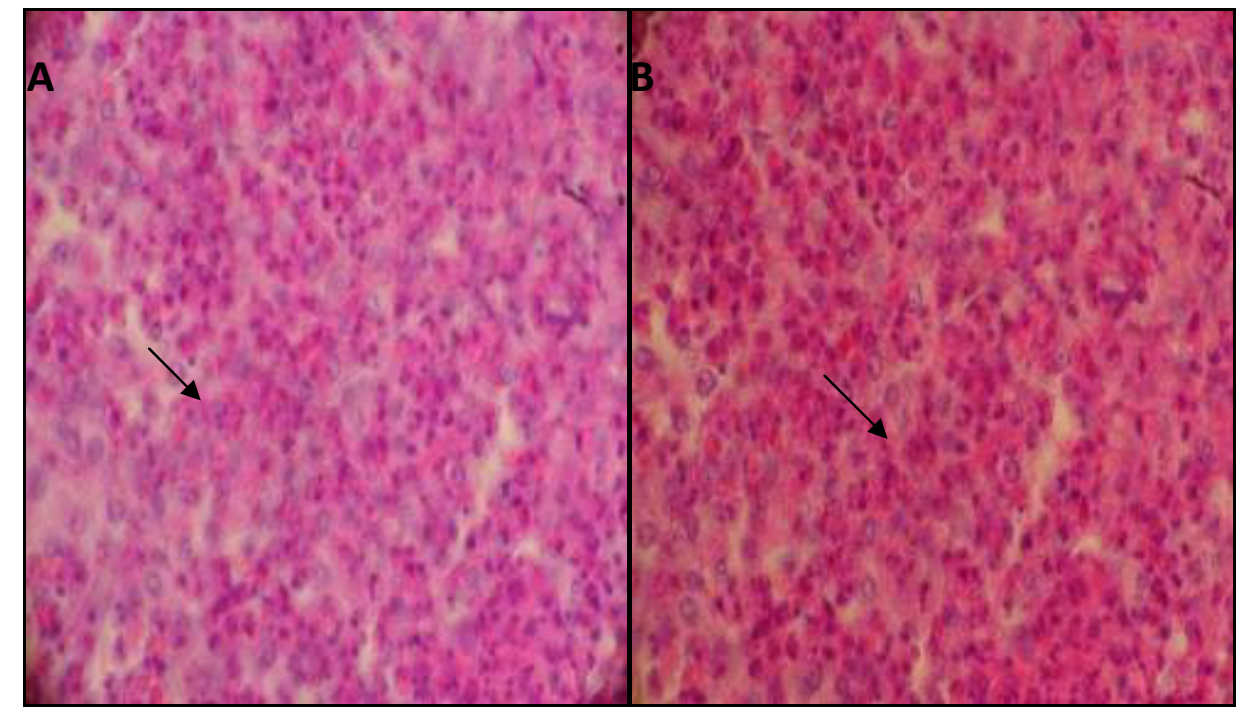

Figura 6: A e B - Microfotografias de figado de frango de corte com 33 dias, apresentando infiltrado de heterófilos (seta), corados em HE, 40X, caracterizando hepatite aguda.

Foi observado em vinte e quatro por cento (24\%) dos fígados: filamentos de fibrina e invasão de tecido conjuntivo fibroso nas áreas as quais haviam presença de heterófilos com aspecto na maioria das vezes picnóticos, caracterizando um granuloma (FIGURA 7).

Por último, foi observado a presença de aglomerados de mielócitos, vinte por cento $(20 \%)$, cujos núcleos são proeminentes e polimórficos, sendo que alguns exibiam figuras de mitose. O citoplasma com presença de grande quantidade de granulações acidófilas, caracterizando uma célula jovem, típica de um oncócito, próprio de uma neoplasia (FIGURA 8). A Figura 9 representa microscopicamente fígado aparentemente normal. 
OLIVEIRA, F.R., MACHADO, F.M.E. e COELHO, H.E. Estudo anatomopatológico de fígados que levam a condenação total de carcaça, na linha de inspeção, durante o abate de frangos de corte (Gallus gallus domesticus) na região do Triângulo Mineiro. PUBVET, Londrina, V. 8, N. 2, Ed. 251, Art. 1662, Janeiro, 2014.

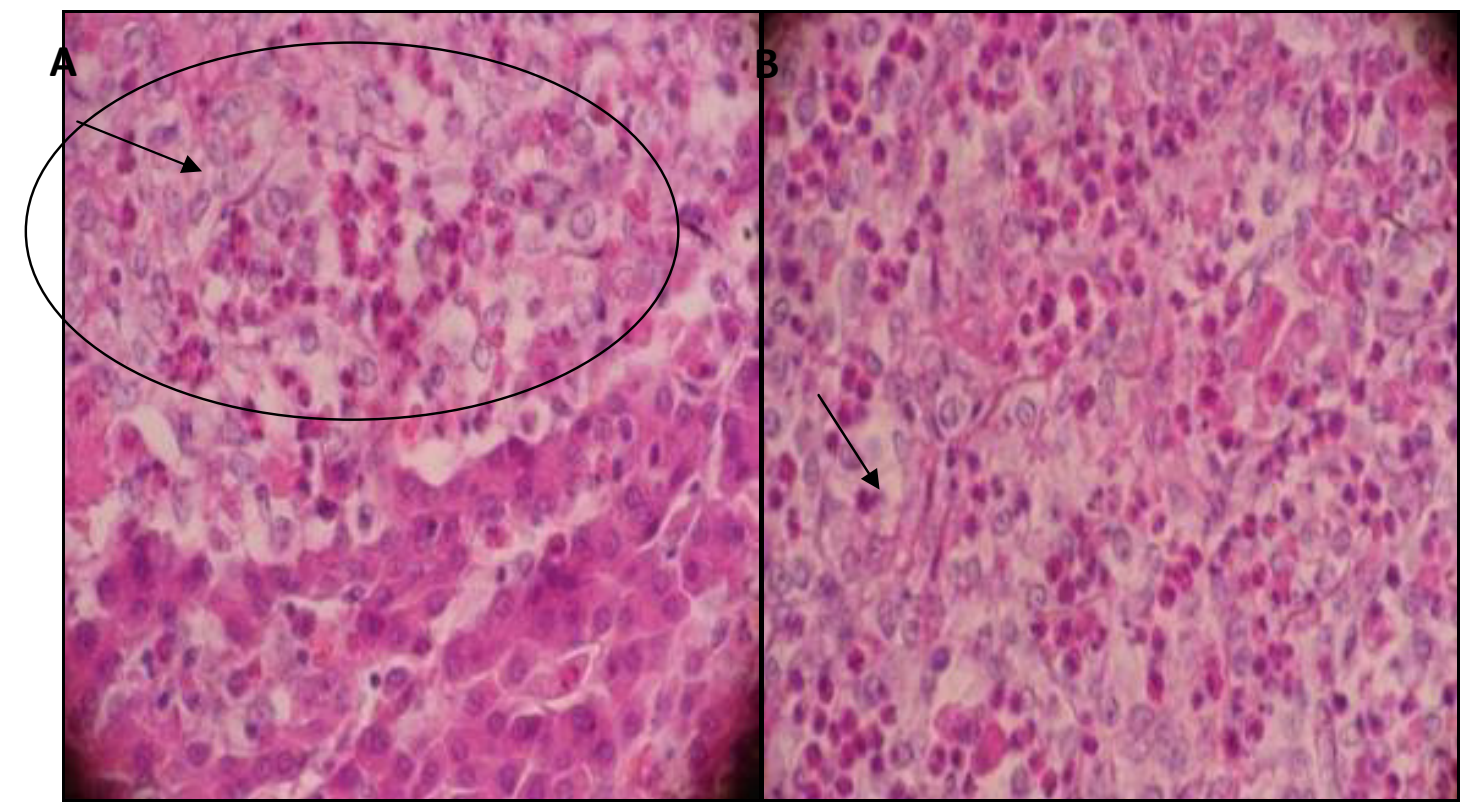

Figura 7: A e B - Microfotografias de fígado de frango de corte com 33 dias, apresentando foco de heterófilos e fibras colágenas (setas) em uma área de necrose (círculo), caracterizando uma inflamação crônica do tipo coligranuloma, corados em HE, 40X.

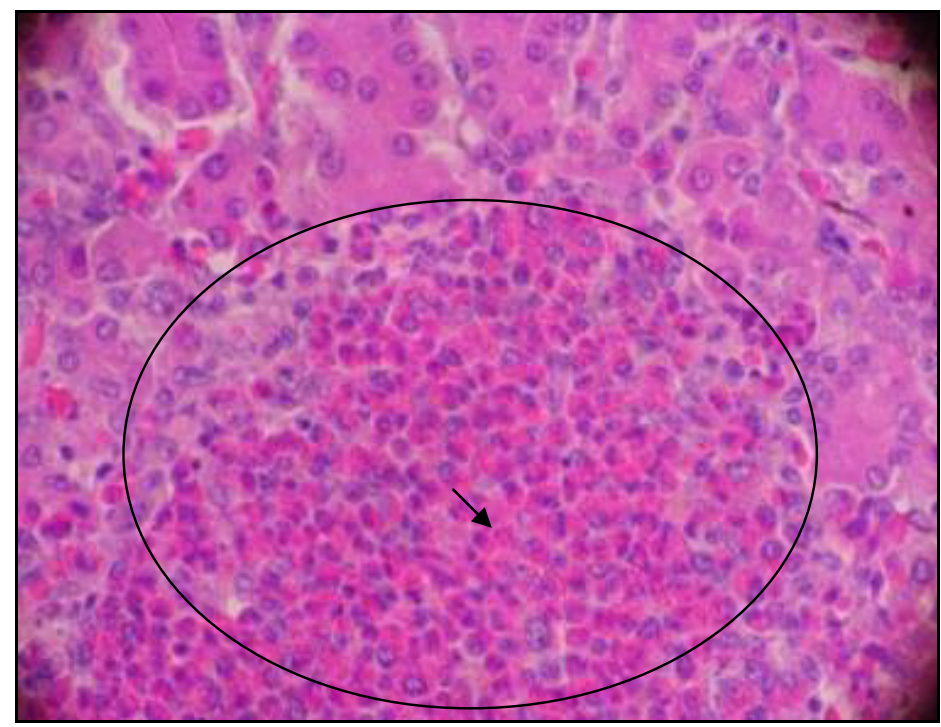

Figura 8: Microfotografia de figado de frango de corte com 33 dias, apresentando aglomerado de mielócitos (círculo) e figuras de mitose (seta), corados em HE, 40X, caracterizando uma neoplasia: Leucose Mielóide. 
OLIVEIRA, F.R., MACHADO, F.M.E. e COELHO, H.E. Estudo anatomopatológico de fígados que levam a condenação total de carcaça, na linha de inspeção, durante o abate de frangos de corte (Gallus gallus domesticus) na região do Triângulo Mineiro. PUBVET, Londrina, V. 8, N. 2, Ed. 251, Art. 1662, Janeiro, 2014.

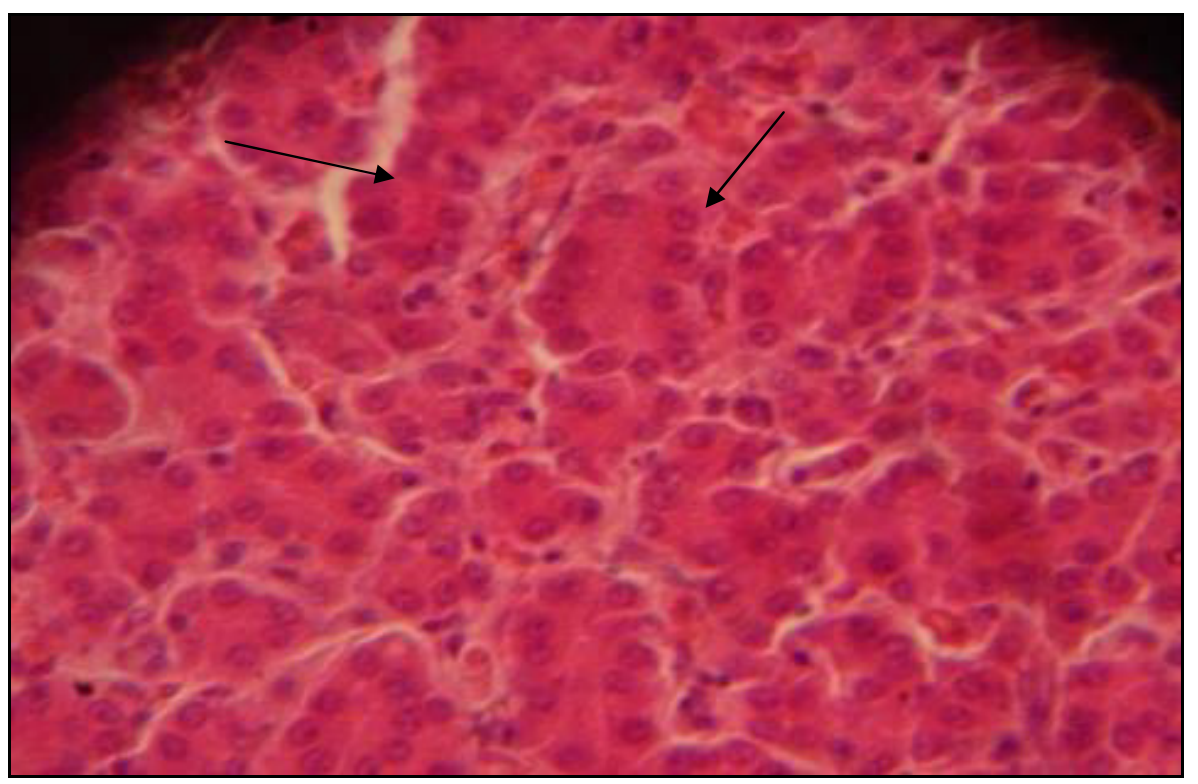

Figura 9: Microfotografia de fígado de frango de corte com 33 dias, aparentemente normal, apresentando cordões hepáticos dulplos (setas), característica exclusiva das aves.

\section{DISCUSSÃO}

$\mathrm{Na}$ análise macroscópica dos fígados no presente trabalho, verificou-se uma semelhança entre as diversas alterações que acometeram os mesmos, o que está coerente com o que relatam Hoerr (1996), Canal e Silva (2000), Manzan (2000), Coelho (2006), e Santos et. al. (2008). Segundo estes autores, os fígados condenados se apresentam, na maioria das vezes, aumentados de volume, com coloração variando entre manchas avermelhadas intercaladas com áreas esverdeadas, amareladas e esbranquiçadas, não permitindo ao inspetor um diagnóstico etiológico seguro compatível com as lesões pertinentes com salmonelose, colibacilose e enfermidades neoplásicas. $\mathrm{Na}$ maioria das vezes o profissional de inspeção, descarta estes fígados com essas lesões como sendo colibacilose e concomitantemente condenam as carcaças segundo Jay (1994) e Pontes (2004). 
OLIVEIRA, F.R., MACHADO, F.M.E. e COELHO, H.E. Estudo anatomopatológico de fígados que levam a condenação total de carcaça, na linha de inspeção, durante o abate de frangos de corte (Gallus gallus domesticus) na região do Triângulo Mineiro. PUBVET, Londrina, V. 8, N. 2, Ed. 251, Art. 1662, Janeiro, 2014.

No trabalho, os achados microscópicos de Heterófilos indica reação bacteriana. Um exemplo seria a $E$. Coli provocando hepatite aguda; já a invasão de tecido conjuntivo nestas áreas tomadas por heterófilos, indica hepatite crônica, no caso, coligranuloma, se o agente for a E. Coli, como relata Coelho (2006); A salmonelose, também é uma reação bacteriana, apresentando infiltração de células do tipo heterófilos em infecções agudas, áreas multifocais a coalescentes de necrose dos hepatócitos, acompanhadas de aglomerados de bastonetes em casos de Salmonella enteriditis segundo os autores Hoerr (1996), Randall e Reece (1996) e Barcelos et. al (2006), que trabalharam com a enfermidade em aves; quando há presença de linfócitos e plasmócitos, a reação é viral, tanto nas inflamações quanto nas neoplasias, como exemplos a leucose linfóide e a Marek, citados por Payne e Fadly (1997) e Coelho (2006) respectivamente. Coelho (2006) ainda afirma que no caso da Marek, os linfócitos tem várias formas, sendo grandes e hipercromáticos com o núcleo proeminente, diferente da leucose que apresenta uniformidade dessas células, como afirma Payne e Fadly (1997); se encontrar células do tipo mielócitos, agrupados, indica neoplasia, que se denomina leucose mielóide conforme relata Manzan (2000) que ao trabalhar com a leucose mielóide em aves, identificou histologicamente as células neoplásicas com pleomorfismo, núcleos ovais, nucléolos proeminentes, cromatina distribuída de maneira irregular, figuras de mitose atípicas e moderada quantidade de citoplasma contendo granulações eosinofílicas esféricas. Essas características indicam a linhagem mielóide.

Confrontando os dados do presente trabalho, no que diz respeito ao exame histopatológico, verificou-se que Rosa et al. ( 1992), Dey et al. (2003), Haider et al. (2004), Barcelos et al. (2006) e Silva et al. (2012), através de seus respectivos trabalhos com fígados provenientes de matadouros avícolas, contaminados pela $E$. Coli, corroboram com os achados histopatológicos neste estudo no que se refere à presença de heterófilos: células inflamatórias indispensáveis na colibacilose. Cinquenta e seis por cento (56\%) das lesões foi 
OLIVEIRA, F.R., MACHADO, F.M.E. e COELHO, H.E. Estudo anatomopatológico de fígados que levam a condenação total de carcaça, na linha de inspeção, durante o abate de frangos de corte (Gallus gallus domesticus) na região do Triângulo Mineiro. PUBVET, Londrina, V. 8, N. 2, Ed. 251, Art. 1662, Janeiro, 2014.

deste infiltrado, o que reforça o diagnóstico compatível com a colibacilose aguda, enquanto vinte e quatro por cento (24\%) havia infiltrado de tecido conjuntivo fibroso, na presença de heterófilos, o que pode representar um quadro crônico da colibacilose: Coligranuloma, provocado pela E.Coli que foi também descrito por Coelho (2006), caracterizado por uma hepatite crônica.

Vinte por cento (20\%) das alterações microscópicas se refere à achados de infiltrados de mielócitos imaturos, própios da leucose mielóide, embora não seja comum nessa etapa de vida das aves, o que está coerente com os relatos de Beyer et al. (1980), Payne (1993), Payne (1998), Ito (1999), Pinto et al. (2003) e Coelho (2006), ao citarem que a leucose mielóide ocorre na fase de maturidade sexual (16 a 22 semanas). $O$ fato do peso das aves serem de 1,3 a $1,6 \mathrm{Kg}$, também contraria os achados desses autores, que afirmam ser a leucose uma enfermidade que acomete aves de linhagem pesada.

As enfermidades neoplásicas: leucose linfóide e doença de Marek, relatados por Payne e Fadly (1997), Back (2002), Coelho (2006) e Santos et al. (2008), não foram observadas no presente trabalho, uma vez que não se verificou nos achados histopatológicos, a presença de mononucleares linfócitos e plasmócitos que surgem na área lesada primordialmente nas manifestações virais, como nos casos das neoplasias em questão.

Com relação à salmonelose relatada por Hoerr (1996), Gast (2003) e Barcelos et al. (2006), as alterações observadas no presente trabalho, não foram suficientes para sugerir um diagnóstico compatível á essa enfermidade, devido a ausência de linfócitos e plasmócitos, além de não apresentarem extensas áreas de necrose, que começam multifocais e vão se coalescendo, além de achados de colangite, conforme relata Ito et al. (2000).

Do ponto de vista epidemiológico, a salmonelose é mais comum em aves adultas e ocorre uma variação de intensidade das lesões, podendo apresentar aves portadoras da enfermidade sem manifestar nenhuma lesão ou sinal clínico. 
OLIVEIRA, F.R., MACHADO, F.M.E. e COELHO, H.E. Estudo anatomopatológico de fígados que levam a condenação total de carcaça, na linha de inspeção, durante o abate de frangos de corte (Gallus gallus domesticus) na região do Triângulo Mineiro. PUBVET, Londrina, V. 8, N. 2, Ed. 251, Art. 1662, Janeiro, 2014.

As aves do presente estudo eram jovens (frangos de corte com 33 dias de vida), o que segundo a bibliografia seria o período que a colibacilose é mais comum, o que se confirmou com este estudo a partir dos achados compatíveis á essa enfermidade.

\section{CONCLUSÃO}

Os achados do presente estudo permitem concluir que: Oitenta por cento (80\%) das lesões hepáticas são compatíveis com colibacilose; cinquenta e seis por cento (56\%) aguda e vinte e quatro por cento (24\%) crônica; enquanto a leucose mielóide representou vinte por cento (20\%) destas lesões.

Com o intuito de cumprir o objetivo do presente trabalho, comunicou-se ao abatedouro os dados observados nesta pesquisa, com o propósito de que as enfermidades aqui relatadas possam ser controladas em suas origens, diminuindo assim as perdas e minimizando os riscos de contaminação na alimentação humana.

O serviço de inspeção apresentou um nível de acerto de $80 \%$, o que se considera desejável, podendo aprimorá-lo.

\section{REFERÊNCIAS}

ABEF. Relatório anual 2012. São Paulo: [online], 2013. Disponível em: <www.abef.com.br>. Acesso em: 29 abr. 2013.

AMORIM NETO, A. A; MIRANDA, C. C. M. Inspeção de aves. In: CURSO DE PÓS-GRADUAÇÃO "LATO SENSU" EM HIGIENE E INSPEÇÃO DE PRODUTOS DE ORIGEM ANIMAL. Goiânia, 2009.

ARRUDA, P. S. Aspectos sanitários da salmonelose como zoonose. Higiene Alimentar, São Paulo, v. 14, n. 71, p. 32-33, 2000.

BACHA, W. J.; BACHA, L. M. Atlas colorido de histologia veterinária. 2. ed. São Paulo: Roca, 2003.

BACK, A. Manual de doenças de aves. Cascavel-PR: Alberto Back, 2002. p.115-119.

BARCELOS, A. S. Avaliação macroscópica, histopatológica e bacteriológica de fígados de frangos (Gallus gallus) condenados no abate pela inspeção sanitária. 2005.

Dissertação (Mestrado em Medicina Veterinária) - Universidade Federal de Santa Maria, Santa Maria - RS, 2005. 
BARCELOS, A. S.; FLÔRES, M. L.; KOMMERS, G. D.; NASCIMENTO, V. P.; SEGABINAZI, S. D.; ANTONIAZZI, T.; BASSAN, J. D. L. Macroscopia, histopatologia e bacteriologia de fígados de frangos (Gallus gallus) condenados no abate. Ciência Rural, v. 36, n. 2, 2006.

BELS, V. Feeding in domestic vertebrates: from structure to behavior. Paris: Cabi Publishing, 2006. 352 p.

BENEZ, S. M. Aves - Criação, clínica, teoria e prática: silvestres, ornamentais, avinhados. 4. ed. Ribeirão Preto, SP: Tecmed, 2004. 600p.

BEYER, J.; NOEL, R.; VOGEL, K.; WERNER, O. E.; PLENIO, C. Studies on the reliability of hard diagnosis os Marek's disease and lymphoid leukosis of chickens on the basis of pathologicnatomical findings. Arch. Exp. Veterinarmed, v. 34, n. 6, p. 826-46, 1980.

BRASIL. Ministério da Agricultura, Pecuária e Abastecimento. Portaria n. 210. Estabelece o Regulamento Técnico da Inspeção Tecnológica e Higiênico-Sanitária de Carne de Aves. Diário Oficial da União, Brasília, 26 nov. 1998. Disponível em:

<http://extranet.agricultura.gov.br/sisleg is-consultarLegislacao.do>. Acesso em: $01 \mathrm{dez}$. 2012.

CALNEK, B. W. Neoplastic diseases. In: Diseases of poultry. 10. ed. [S.I.]: MosbyWolfe, 1997. Cap. 17, p. 367-401.

CANAL, C. W.; SILVA, E. N. Enfermidade de Marek, complexo leucócito Aviário e Reticuloendoteliose. In: BERCHIERI JÚNIOR, A.; MACARI, M. Doenças das Aves. CampinasSP: FACTA, 2000. p. 257-260.

COELHO, H. E. Patologia das aves. São Paulo-SP: Tecmedd, 2006.

DEY, B. P.; CHEN, Y. R.; HSIEH, C.; CHAN, D. E. Detection of septicemia in chicken livers by spectroscopy. Poultry Science, [S.I.], v.82, p.199-206, 2003.

DICE, K. M.; SACK, W. O.; WENSING, C. J. G. Tratado de anatomia veterinária. 3. ed. Rio de Janeiro: Elsevier, 2004.

DORN, P. Manual de patologia aviária. Zaragoza: Acribia, 1973.

FADLY, A. M.; CRITTENDEN, L. B. Avian (poultry). In: Veterinary Cancer Medicine. 2. ed. 1987. p. 443-454.

FADLY, A. M.; SMITH, E. J. Isolation and some characteristics of a subgroup J-like Avian Leukosis Virus associated with Myeloid Leukosis in meat-type chickens in the United States. Avian Diseases, [S.I.], v.43, n.3, p. 391-400, 1999.

FERREIRA, A. J. P.; ITO, N. M. K.; BENEZ, S. M. et al. Infecção natural e experimental por Salmonella enteriditis em pintos. In: CONFERÊNCIA APINCO DE CIÊNCIA E TECNOLOGIA AVÍCOLAS, Campinas, 1990. Anais... Campinas: FACTA, 1990. p. 171.

FERREIRA, A.J.P.; KNÖBL, T. Colibacilose Aviária. In: MACARI, M.; BERCHIERI JÚNIOR. Doenças das aves. Campinas: Facta, 2000. p. 197-208.

GAST, R. K. Paratyphoid infections. In.: SAIF, Y. M. Diseases of Poultry. 11. ed. Ames, Iowa: Iowa State Press, 2003. p. 583-613.

GROSS, W. G. The development of "Air Sac Diseases". Avian Dis., [S.I], v.5, p. 431-439, 1961.

GROSS, W.G. Diseases due to Escherichia coli in Poultry. In: Escherichia coli in domestic animals and humans. UK: Gyles, 1994. p. 237-260. 
HAIDER, M.G.; HOSSAIN, M.G.; HOSSAIN, M.S.; CHOWDHURY, E.H.; DAS, P.M.; HOSSAIN, M.M. Isolation and characterization of Enterobacteria associated with health and disease in sonali chickens. Journal of Veterinary Medicine, Bangladesh, v. 2, n. 1, p. 15-21, 2004.

HAM, W. A.; M. B.; F.R.S.C.; D.SC. Histopatologia. 6. ed. Rio de Janeiro: Guanabara Koogan, 1972.

HOERR, F. J. Liver. In.: RIDDELL, C. Avian histopathology. Pensylvania: Library of Congress, 1996. p. 143-166.

ITO, N. M. K. Doença de marek no brasil. In: SIMPÓSIO SOBRE ONCOVÍRUS AVIÁRIOS. [S.I.]: EMBRAPA, 1999.

ITO, N. M. K.; MIYAJI, C. I.; LIMA, E. A.; OKABAYASHI, S. Enfermidades do Sistema Digestório e Anexos. In: BERCHIERI; MACARI. Doença das Aves. Campinas: FACTA, 2000. p. 56.

JAY, J. M. Microbiologia moderna de los alimentos. 3. ed. Zaragoza: Acribia, 1994. p. 804.

JORDAN, F. T.; PATTISON, M. Poultry diseases. 4. ed. Philadelphia: WB Saunders, 1996. p. 123-133.

JUNQUEIRA, L. C; CARNEIRO, J. Histologia básica. 11. ed. Rio de Janeiro: Guanabara Koogan, 2008.

LANG, M. Controle da doença respiratória de frangos de corte. Avicultura e Suinocultura Industrial, [S.I.], n. 992, p. 78-79, 1992.

LOVLAND, A.; KALDHUSDAL, M. Severely impaired production performance in broiler flocks with high incidence of Clostridium perfringens associated hepatitis. Avian Pathology, [S.I.], v. 30, p. 73-81, 2001.

LUNA, L. G. Routine staining procedures. In: MANUAL OF HISTOLOGIC STAINING METHODS OF THE ARMED FORCES INSTITUTE OF PATHOLOGY. 3. ed. New York: Mac GrowHill Book, 1968. p. 32-46.

MACLACHLAN, N. J.; CULLEN, J. M. Fígado, sistema biliar e pâncreas exócrino. In: THOMSON, R.G. Patologia Veterinária Especial. 2. ed. Porto Alegre: Artmed, 1998. p. 265-298.

MANZAN, R. M. Leucose mielóide: localizações atípicas dos tumores e detecção do VLA-J através da PCR. Revista Brasileira de Ciência Avícola, suplemento 2, p. 84, 2000.

McKAY, J. C. A poultry breeder's approach to avian neoplasia. Avian Pathology, v. 27, p. 7475, 1998.

MOORHEAD, P. D.; SAIF, G. M. Mycoplasma meleagridis and Escherichia coli infections in germfree and specific pathologic manifestation. Am. J. Vet. Res., v. 31, p. 1645-1653, 1970.

NAGARAJA, K.V. Patogenicidad de la Escherichia coli y los factores de stress en lós pollos de engorde. Avicultura Profesional, v. 10, p. 176-180, 1993.

NAKAMURA, K. Effect of infectious bursal diseases virus on infection produced by Escherichia coli of high and low virulence in chickens. Avian Pathology, v. 19, p.713-21, 1990.

OLIVEIRA, A. S. C. Perfil de resistência a antimicrobianos de Salmonella enteritidis e Salmonella thyphimurium isoladas de miúdos de aves em Goiás. Revista Brasileira de Ciência Avícola, Suplemento 6, p. 195, 2004.

PAYNE, L. N. Avian leukosis /sarcoma. In: Science Publishers, 1993. cap. 28, p. 411-433. . Virus infections of birds. [S.I.]: Elsebier 
PAYNE, L. N.; FADLY, A. M. Leukosis/sarcoma group. In: CALNEK, B.W. et al. Diseases of Poultry. 10. Iowa: Iowa State University Press, 1997. p. 414-466.

PAYNE, L.N. HPRS-103: a retrovirus strikes back. The emergence of subgroup J avian leukosis virus. Avian Pathology, v. 27, p. S36-S45, 1998.

PAYNE, L.N.; McKAY, J.C. Diagnóstico diferencial de las leucosis aviares y el linfoma de la enfermedad de Marek y los procedimientos para erradicar los vírus exógenos de la leucosis aviar. In: CONGRESO LATINOAMERICANO DE AVICULTURA, 16., Lima. Anais... Lima: Associación Latinoamericana de Avicultura, 1999. p. 68-74.

PENHA, G.A; SUZUKI, E.Y.; UEDA, F. S.; PERES, R. E. P. et al. Diagnóstico da salmonelose e sua importância para a avicultura: revisão de literatura. Revista científica eletrônica de medicina veterinária, n. 10, 2008.

PINTO, M. V.; MATEUS, A.; SEIXAS, F. et al O papel da inspeção sanitária post mortem em matadouro na detecção de lesões e processos patológicos em aves. Quatro casos de lesões compatíveis com a doença de Marek em carcaças de aves rejeitadas. Revista Portuguesa de Medicina Veterinária, Lisboa - Portugal, v. 98, p. 145-148, 2003.

PONTES, A.P. Programa de controle de Salmonella em abatedouros de aves. In: CONFERÊNCIA APINCO DE CIÊNCIA ENTECNOLOGIA AVÍCOLA. Santos. Anais... Santos-SP: [s.n], 2004. p.102.

POWELL, P.C. E PAYNE, L.N. Marek's disease. In: Elsevier Science Publishers, 1993. cap. 3, p.37-73. . Virus infections of birds. [S.I.]:

RANDALL, C. J.; REECE, R. L. Color atlas of avian histopathology. Turin: Mosby-Wolfe, 1996, p. 232.

RITCHIE, B.W. Avian Viruses: function and control. Florida-EUA: Wingers Publishing, 1995, cap. 7, p. 200-204.

ROCHA, J. R.; ANTONIO, N.S.; PEREIRA, R. E. P.; LOT, R.F.E. Leucose Aviária: Relato De Caso. Revista Científica Eletrônica De Medicina Veterinária, ano VII, n. 13, 2009.

ROSA, M.; FICKEN, M. D.; BARNES, H. J. et al. Acute airsacculitis in untreated and cyclophosphamide-pretreated broiler chickens inoculated with Escherichia coli or Escherichia coli cell free culture filtrate. Vet. Pathol., v. 29, p. 68-78, 1992.

SANTOS, B. M.; MOREIRA, M. A.; DIAS, C. C. A. et al. Manual de doenças avícolas. Viçosa, MG: Ed. UFV, 2008. p. 224.

SILVA, A. B. Colibacilose. Porto Alegre: Centro de Diagnóstico e Pesquisa em Patologia Aviária, Faculdade de Veterinária/IPVDF. Universidade Federal do Rio Grande do Sul, 1992. 8 p.

SILVA, I. M. M.; BALIZA, M.; SANTOS, M. P. et al. Presença de Escherichia coli em fígados de frangos provenientes de matadouros avícolas. Revista Brasileira de Saúde e Produção Animal, Salvador, v. 13, n. 3, p. 694-700, jul./set., 2012.

SILVA, N. E.; DUARTE, A. Salmonella Enteritidis em Aves: Retrospectiva no Brasil. Revista Brasileira de Ciência Avícola, v. 4, n. 2, p. 85 - 100, 2002.

YODER, H. W.; BEARD, C. W.; MITCHELL, B. W. Pathogenicity of Escherichia coli in aerosol for young chickens. Avian Diseases, [S.I.], v. 33, n. 4, p. 676-683, 1989.

ZAVALA, G. Actualidades en investigación sobre Virus de Leucosis subgrupo J. In: CONGRESO LATINOAMERICANO DE AVICULTURA, 16. Lima, Peru. Anais... Lima, Peru: [s.n], 1999. p.45-46. 